\title{
舫 New Disease Reports \\ A bacterial leaf spot and shoot blight of lavender caused by Xanthomonas hortorum in the UK
}

\author{
S.J. Roberts ${ }^{1 *}$ and N.M. Parkinson ${ }^{2}$ \\ ${ }^{1}$ Plant Health Solutions, 20 Beauchamp Road, Warwick, CV34 5NU, UK ; ${ }^{2}$ The Food and Environment Research Agency, \\ Sand Hutton, York, YO41 1LZ, UK
}

*E-mail: s.roberts@planthealth.co.uk

Received: 20 Jul 2014. Published: 14 Jul 2014. Keywords: plants, diseases, bacteria, herbaceous perennials, ornamentals

English lavender (Lavandula angustifolia) is grown as a flowering perennial ornamental in UK gardens. It is an important crop for some commercial nurseries that produce large numbers of plants for retail sale in garden centres. During a survey of bacterial diseases of herbaceous perennials in 2010 (Roberts, 2011), symptoms consisting of brown to dark brown irregular leaf spots with a water-soaked margin were observed on the leaves of containerised plants growing at one nursery (Fig. 1). About $75 \%$ of plants were affected and considered to be un-marketable.

Microscopic observation of lesions comminuted in drops of sterile nutrient broth revealed large numbers of bacteria streaming from the cut edges. Suspensions were streaked on plates of yeast dextrose chalk agar (YDC), and 5\% sucrose nutrient agar (SNA), and produced a slow-growing paleyellow mucoid Xanthomonas-like bacterium following incubation for two to four days. Isolates were Gram-negative, catalase positive, oxidase negative, and aesculin positive (Lelliot \& Stead, 1988), and produced yellowing, but no necrosis in tobacco hypersensitivity tests.

Young leaves of $L$. angustifolia, in $7 \mathrm{~cm}$ pots, were inoculated by stabbing with a sterile insect pin charged with growth from 48 hour cultures growing on YDC. Plants were enclosed in polythene bags for 48 hours to maintain high humidity and grown on in a glasshouse with minimum temperatures of $18 / 15^{\circ} \mathrm{C}$ (day/night). Control plants were stabbed with a sterile insect pin. Symptoms typical of those observed on the nurseries began to appear after 7 to 14 days on inoculated leaves (Fig. 2), and were absent on control plants. Re-isolations on YDC yielded pure cultures of bacteria with characteristics identical to those of the inoculated isolates. Sequencing of the gyrB gene from two isolates (9125, 9207; GenBank Accession Nos. KF924198, KF924197) (Parkinson et al., 2009) indicated over 99\% identity to strains of Xanthomonas hortorum. We therefore identify them as X. hortorum.

This is the first formal report of a bacterial leaf spot of lavender in the UK caused by $X$. hortorum. There has been a previous report (Koike et al., 1995) of a similar disease of lavender in California, USA, where the causal bacterium was identified as Xanthomonas campestris. Due to changes in taxonony/nomenclature we presume that this is the same disease and pathogen. In addition, sequences have recently been deposited in GenBank (Accession nos. AB809607, AB809609, AB809610) for strains of $X$. hortorum from lavender in Japan, but there has been no published report. Subsequent to the survey, the disease has been seen on other commercial nurseries, on plants for retail sale in different parts of the UK (Fig. 3), and also on 'plug-plants' delivered to a UK nursery from the Netherlands. Symptoms can be difficult to distinguish from those caused by the fungal pathogens Septoria lavandulae and Phomopsis lavandulae. We therefore suspect that the disease may be widespread on lavender but is underreported.

\section{Acknowledgements}

The authors would like to thank the nurseries that took part in the survey. Part of the work was funded by the Horticulture Development Company (www.hdc.org.uk).

\section{References}

Koike, ST, Tjosvold SA, Cooksey DA, Azad HR. 1995. A bacterial disease of lavender caused by Xanthomonas campestris. Plant Disease 79, 859.

Lelliott RA, Stead DE, 1988. Methods for the Diagnosis of Bacterial Diseases of Plants. Oxford, UK: Blackwell Scientific.

Parkinson N, Cowie C, Heeney J, Stead D. 2009. Phylogenetic structure of Xanthomonas determined by comparison of gyrB sequences. International Journal of Systematic and Evolutionary Microbiology 59, 264-274. http://dx.doi.org/10.1099/ijs.0.65825-0

Roberts S J. 2011. Bacterial diseases of herbaceous perennials. HDC Project HNS 178, Annual Report 2010-11. Stoneleigh, UK: AHDB. http:// www.hdc.org.uk/sites/default/files/research_papers/HNS\%20178\%20year $\% 201 \% 20$ report.pdf

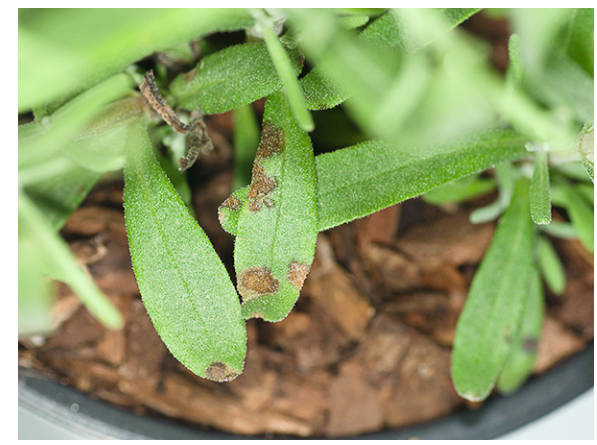

Figure 1

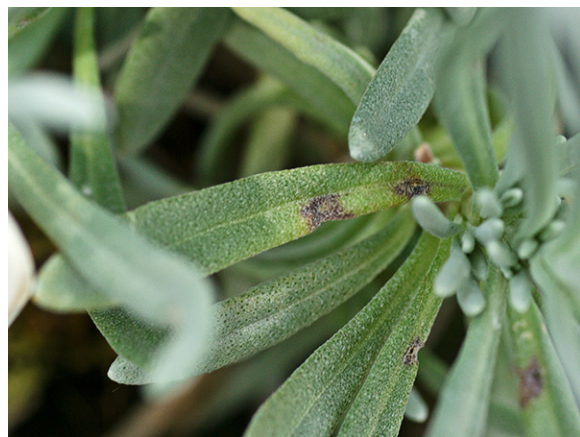

Figure 2

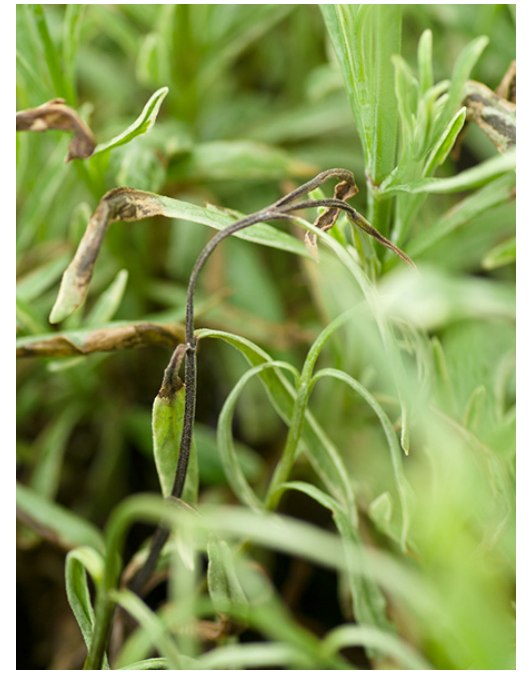

Figure 3

To cite this report: Roberts SJ, Parkinson NM, 2014. A bacterial leaf spot and shoot blight of lavender caused by Xanthomonas hortorum in the UK. New Disease Reports 30, 1. http://dx.doi.org/10.5197/j.2044-0588.2014.030.001

(c) 2014 The Authors

This report was published on-line at www.ndrs.org.uk where high quality versions of the figures can be found. 